\title{
HUKUM YANG DITERIMA DAN DITENTANG
}

\author{
Disusun Oleh: \\ FIRE CARLIS
}

\begin{abstract}
Abstrak
Keamanan dan ketertiban dapat berjalan sebagaimana mestinya ketika ada norma dalam hal ini norma hukum. Hukum ini sangat berpengaruh terhadap kepastian kehidupan suatu Negara. Adanya hukum, maka adanya kenyamanan. Namun hukum ini tidak selamanya dapat diterima dengan baik oleh setiap orang, karena adakalanya hukum yang ada bias menjadi ancaman bagi orang tertentu maupun orang banyak. Kondisi ini menarik untuk dicermati lebih jauh lagi supaya ada gambaran atau fakta atas suatu abstraksi hukum. Tulisan ini ditelusuri berdasarkan metode penelitian hukum sosiologi yang mana didasarkan juga pada metode penelitian doctrinal yang semi........
\end{abstract}

Kata Kunci: Hukum, Diterima, Ditentang.

\section{DAFTAR PUSTAKA}

Nurmardiansyah, Eko. "Eco-Philosophy dan Implikasinya dalam Politik Hukum Lingkungan di Indonesia." Melintas 30.1 (2014): 70-104.

Saraswati, R. (2014). Arah Politik Hukum Pengaturan Desa ke Depan (Ius Constituendum). Masalah-Masalah Hukum, 43(3), 313-321.

Telaumbanua, Dalinama. 2018. “Pembentukan Peraturan Daerah Kabupaten/Kota.” Jurnal Education and Development. vol. 4, no. 1

MD, Mahfud, Politik Hukum Di Indonesia, RajaGrafindo Persada, Jakarta, 2009.

Telaumbanua, Dalinama. 2019. “Kumpulan Undang-undang KPK Dalam Satu Naskah.” LawArXiv. November 29. doi:10.31228/osf.io/ysju2.

http://www.lombalomba.com/?s=penegakan+hukum+orde+lama

Telaumbanua, Dalinama. 2020. "Restriktif Status Dewan Pengawas KPK." Jurnal Education and Development. vol. 8, no. 1 
https://osf.io/xtdba/download?format=pdf http://id.wikipedia.org/wiki/Orde_Baru

Telaumbanua, Dalinama. 2019. Hukum Ketenagakerjaan. Deepublish.

Telaumbanua, Dalinama. 2019. "Analisis Peraturan Perundang-undangan Koperasi Dengan Tujuan Hukum."

https://www.kompasiana.com/ismawati26/5cd2480275065753492fc712/politik-dalamhukum-di-indonesia

https://www.researchgate.net/publication/337241250_Politik_Hukum_di_Indonesia

http://ditjenpp.kemenkumham.go.id/htn-dan-puu/480-politik-perundang-undangan.html 